\title{
INOVACIJŲ PARTNERYSTĖS ŽEMĖS ŪKYJE EFEKTYVUMO VERTINIMAS
}

\author{
Jurgita Baranauskiené $\dot{1}^{1}$, Rasa Pakeltiené2, Antanas Maziliauskas ${ }^{3}$ \\ ${ }^{1}$ Doc. dr. Vytauto Didžiojo Universitetas. Universiteto g. 10, Akademija, Kauno raj., Lietuva. \\ El.paštas jurgita.baranauskiene@vdu.lt \\ ${ }^{2}$ Doc. dr. Vytauto Didžiojo Universitetas. Universiteto g. 10, Akademija, Kauno raj., Lietuva. \\ El.paštas rasa.pakeltiene@vdu.lt \\ ${ }^{3}$ Prof. dr. Vytauto Didžiojo Universitetas. Universiteto g. 10, Akademija, Kauno raj., Lietuva. \\ El.paštas antanas.maziliauskas@vdu.lt
}

\begin{abstract}
Žemès ūkio Europos inovaciju partnerystę (angl. European Innovation Partnership in Agriculture EIP-AGRI) inicijavo Europos Komisija siekiant socialinės naudos ir bendro ūkio modernizavimo diegiant inovacijas. Skatinant bendradarbiavimą tarp mokslininkų, žemės ūkio konsultantų ir ūkininkų tikimasi pasiekti geresnių ir greitesnių rezultatų. Dar 2016 metais Lietuvoje pradèti ịgyvendinti inovacijų partnerystès veiklos grupių žemės ūkyje projektai. Pagrindinè problema - kaip ịvertinti inovacijos partnerystès projektų žemès ūkyje efektyvumą, kokiais rodikliais ji apibrèžti ir išmatuoti? Šiai problemai spręsti reikalinga inovacijų partnerystès efektyvumo žemès ūkyje vertinimo metodika. Šiame straipsnyje pristatoma inovacijų partnerystės žemės ūkyje efektyvumo vertinimo metodika, kurioje detalizuojami atrinkti vertinimo rodikliai, nustatytas jų reikšmingumas, sudarytos efektyvumo vertinimo rezultatų interpretavimo gairès. Sudaryta vertinimo metodika testuota panaudojant Lietuvoje veikiančių EIP grupių projektų duomenis. Inovacijų partnerystės žemės ūkyje efektyvumo vertinimo metodika aktuali tiek moksliniu tiek praktiniu požiūriu.
\end{abstract}

Raktiniai žodžiai: inovaciju partnerystè, žemès ūkis, efektyvumas.

JEL kodai: R10, R11, R58.

\section{Ivadas}

Europos inovacijų partnerystė (toliau EIP) yra platforma, kurios tikslas - šalinti Europos tyrimų ir inovacijų sistemoje atsiradusius trūkumus ir kliūtis, trukdančias arba vilkinančias kurti ir diegti ị rinką idejjas. Europos inovacijų partnerystès kuriamos siekiant ịveikti žaliavų trūkumą Europoje, palaikyti aktyvų ir sveiką senejjimą, vystyti pažangius miestus ir bendruomenes, užtikrinti sveiką ir švarų vandenį, taip pat skatinti žemès ūkio inovacijas sprendžiant visuomenès gyvenimo kokybès ir darnaus žemès ūkio vystymosi problemas.

Europos inovacijų partnerystė žemès ūkio srityje, laikomas bendradarbiavimo modeliu, kuriuo tikimasi efektyvios tarp-sektorinės ir tarp-institucinės komunikacijos, sprendžiant konkurencingumo ir tvaraus žemès ir miškų ūkio vystymosi, kurių pasekmè - išspręstos tvaraus sektorių vystymosi problemos ir įdiegtos inovacijos.

Inovacijų diegimas Lietuvos ūkininkų ūkiuose nèra naujovè - tokios veiklos remtos pagal Lietuvos kaimo plètros 2007-2013 m. programą. EIP iniciatyva, kuri igyvendinama 2014-2020 m. finansavimo laikotarpiu, skirta šalinti Europos tyrimų ir inovacijų sistemoje atsiradusius trūkumus ir kliūtis, trukdančias arba vilkinančias spręsti konkrečias ūkininkams iškilusias problemas, diegti inovacijas, kurios svarbios siekint, kurti ir diegti ị rinką konkurencingus žemès ūkio produktus, technologijas ir paslaugas.

Esminè Europos inovacijų partnerystès (EIP-AGRI) idèja - paskatinti žemès ūkio modernizavimą, inovacijų žemès ūkio sektoriuje diegimą, todèl EIP efektyvumo vertinimą galima sieti su inovacijų diegimo efektyvumo vertinimu žemès ūkio sektoriuje.

Copyright (C) 2020. Published by Vytautas Magnus University. This is an open access article distributed under the terms of the Creative Commons Attribution Non-Commercial 4.0 (CC BY-NC 4.0) license, which permits unrestricted use, distribution, and reproduction in any medium provided the original author and source are credited. The material cannot be used for commercial purposes. 
Europos Komisija yra parengusi keletą įrankių nacionalinių Kaimo plètros programu vertinimui. Bendra stebėsenos ir vertinimo sistema pateikia pagrindinį vertinimo elementų rinkini (bendrus rezultatų rodiklius), kad būtų atsakyta į atitinkamus bendrus vertinimo klausimus (Common evaluation questions ..., 2015).

2017 metais, Europos Komisijos užsakymu „The Evaluation Help Desk“ parenge rekomendacinį kaimo plètros programų 2014-2020 inovacijų vertinimo gidą . Dokumente pirmiausia apibrèžiama inovacija, kurios suvokimo kompleksiškumas aiškinamas jos pritaikomumu skirtingoms socialinėms ir ekonominėms bei aplinkos situacijoms visoje ES analizuoti ir vertinti. Jis susijęs su KPP ,architektūra“, gebejjimu įsitraukti ị esamą aplinką ir užtikrinti naujus kaimo iššūkių ir poreikių sprendimus (European Commision..., 2017). Reikia pažymèti, kad Europos komisijos parengti vertinimo klausimai, gairès skirtos Kaimo plètros programų vertinimui, o ne konkretaus EIP projekto ar EIP veiklos grupès efektyvumo įvertinimui.

Linzalone ir Schiuma (2015) analizavo ịvairus projektų efektyvumo vertinimo modelius, kurie apima įvairius efektyvumo kriterijus, susijusius su projekto kaštais, progresu, laukiamomis naudomis, rezultatais. Šių mokslininkų teigimų, efektyvumo vertinimas turi būti kompleksiškas, analizuojami skirtingi aspektai, o tikslas nustatyti, ne tik kas įvyko, tačiau numatyti laukiamas pasekmes, kurios leistų koreguoti vertinamo projekto eigą.

Mokslininkai dažnai naudoja Kaštų efektyvumo analizès metodą, kuris apima visų kaštų ir laukiamų naudų analizę, kai siekiama pasirinkti pigiausią variantą bei suteikia galimybę išsiaiškinti kokiais ištekliais ir priemonėmis bus pasiekti laukiami rezultatai (Ernst, 2006; Edlin ir kt., 2015; Aparicio ir kt., 2016; Dudycz ir kt., 2017).

Literatūroje pasigendama vieningų žemės ūkio projektų, veiklų, partnerystės efektyvumo ar inovacijų diegimo efektyvumo vertinimo įrankių. Dažnai nagrinèjami kiti sektoriai, tačiau žemès ūkis yra specifinis ir efektyvumo vertinimas turi atliepti svarbiausias ES strategijas, tokias kaip Europos Komisijos Strateginis planas žemės ūkiui 2016-2020, Europos Darnaus vystymosi tikslus (The 2030 Agenda for Sustainable Development, 2015), Europos Žaliajį kursą (The European Green Deal, 2019) ir kt.

Allen ir kt. (2020) pateikia bio-projektų vertinimo gaires, kuriose pateikiama vertinimo metodika glaudžiai susieta su tvaraus vystymosi tikslais. Tačiau šios gairès pilnai neatliepia mokslininkų, konsultantų ir ūkininkų partnerystès idèjos.

Maziliauskas ir kt. (2018) nagrinėjo Europos inovacijų partnerystės žemės ūkyje efektyvumą įtakojančius vidinius ir išorinius veiksnius, tačiau pats EIP projektų efektyvumo terminas liko neapibrèžtas ir neįvertinamas. Apskritai, kalbant apie žemès ūkio sektorių, lieka neatsakyti klausimai - kada projektą galima vadinti efektyviu, kokiais rodikliais įvertinti projekto efektyvumą, kaip palyginti projektus ir pasirinkti efektyviausią?

Moksline problema - kokiais principais ir metodais ịvertinti inovacijų partnerystès efektyvumą žemès ūkyje?

Tyrimo objektas - inovacijų partnerystès efektyvumas žemės ūkyje.

Tikslas - išanalizavus inovacijų partnerystės žemės ūkyje efektyvumo vertinimo ypatumus ir atrinkus efektyvumą nusakančius rodiklius, sudaryti inovacijų partnerystès žemės ūkyje efektyvumo vertinimo metodiką.

Uždaviniai:

1. Apžvelgti EIP efektyvumo vertinimo prielaidas, suformuluoti vertinimo principus

2. Atrinkti EIP efektyvumo vertinimo rodiklius

3. Sudaryti EIP efektyvumo vertinimo metodiką

Tyrimo metodai: Mokslinei problemai tirti naudojami mokslinès literatūros analizè, lyginamoji analizè, sisteminè analizè, dokumentų analizè, apibendrinamoji analizè bei kiti bendramoksliniai metodai. Inovacijų partnerystès efektyvumo žemès ūkyje vertinimo metodika pagrịsta ekspertinio vertinimo rezultatais. Metodika buvo testuota naudojant Lietuvos EIP projektų duomenis. 


\section{Tyrimo rezultatai ir jų aptarimas}

\section{etapai \\ 2.1. Inovacijų partnerystès žemės ūkyje efektyvumo vertinimo principai, prielaidos ir}

Efektyvumas gali būti apibūdinamas kaštų minimizavimo ir tikslų pasiekimo požiūriu (Vaitkevičiūtè, 2001). Efektyvumo terminas persipynęs su veiksmingumo, produktyvumo, rezultatyvumo sąvokomis. Anglų kalboje efektyvumui išreikšti naudojami du terminai: „effectiveness“ - apibrèžiamas, kaip laukiamo rezultato pasiekimo sėkmingumas, o „efficiency“ siejamas su naudos ir kaštų santykiu, t. y. akcentuojamas laiko ir materialiųjų kaštų minimizavimas. Pažymime, kad šiame tyrime Inovacijų partnerystės žemès ūkyje efektyvumo vertinimo metodika siejama su išsikeltų tikslų ir laukiamų rezultatų pasiekimu.

Siekiant sukurti inovacijų partnerystės žemès ūkyje efektyvumo vertinimo metodiką, tikslinga suformuluoti vertinimo principus:

- Nuoseklumo - vertinimo procesas turi būti nuoseklus, apimantis problemos, kurią spręs EIP veiklos grupé, formuluojamų tikslų, vykdomų veiklų partnerių bendradarbiavimo ir laukiamo poveikio analizę.

- Paprastumo - vertinimo metodika turi būti nesunkiai pritaikoma įvairiu EIP veiklos grupių veiklos ar atskirų ju projektų vertinimui, nereikalaujanti specifinio vertintojo pasirengimo, dideliu laiko ir finansinių sąnaudų, o gauti vertinimo rezultatai nesunkiai interpretuojami.

- Pagristumo - pagal ši principą vertinama efektyvumo rodiklių skaitinè reikšmè turi būti pagrịsta logiškomis prielaidomis.

- Palyginamumo - gautas vertinimo rezultatas, t. y. apibendrinta inovacijų partnerystès efektyvumo vertinimo skaitinè reikšmè turi būti palyginama su kitos EIP veiklos grupès efektyvumo vertinimo skaitine reikšme.

- Plataus pritaikomumo - vertinimo metodika turi būti pritaikoma inovacijų partnerystès žemès ūkyje efektyvumui vertinti, nepriklausomai nuo EIP veiklos grupės dydžio, sprendžiamų žemès ūkio problemų ar diegiamų inovacijų pobūdžio, projekto ịgyvendinimo geografinès padėties, veikiančių politinių, kultūrinių, religinių ir kt. aplinkybių (Baranauskienė, 2015).

Inovacijų partnerystès žemės ūkyje efektyvumo vertinimui svarbi vertintojo kompetencija ir patirtis, jo siekis, gebejjimai ir galimybès įsigilinti bei perprasti vertinamos EIP veiklos grupès sprendžiamas problemas, ịgyvendinamo projekto esmę ir kitas įtakojančias aplinkybes.

Ekspertų atliekamą inovacijų partnerystès efektyvumą apibūdinančių rodiklių vertinimą galima vadinti irodymais grịstu vertinimu. Tai toks vertinimas, kurio metu remiamasi tiek moksliniais praktiniais irodymais, tiek teorinemis žiniomis kiekviename ịvertinimo proceso etape (žr. 1 pav.). Irodymai grịsto vertinimo metu, ekspertai(-as) naudoja iš anksto parengtą klausimyną, formuliarus ir pokalbio metu su vertinimo proceso dalyviais (EIP veiklos grupès nariais), ji pildo. Esant poreikiui, vertinimui gali būti pateikti rodiklius pagrindžiantys dokumentai. Antrajame vertinimo proceso žingsnyje, ekspertas apdoroja gautą informaciją - atlieka galutinị ịvertinimą ir ji pateikia ataskaitoje.

Inovaciju partnerystès žemès ükyje efektyvumo vertinimo prielaidos. Inovacijų partnerystès žemès ūkyje efektyvumo vertinimo metodika skirta EIP veiklos gupių veiklos ar jų vykdomų projektų vertinimui, kai poveikis tiesiogiai nukreiptas i konkrečių žemės ūkio problemų sprendimą, atsiribojant nuo išskirtinių atvejų, eksperimentų, kuriems esant laukiamas ir modeliuojamas neịprastas bendradarbiavimas ir dèl to atsirandantis neịprastas veiklų poveikis.

Inovacijų partnerystės žemės ūkyje efektyvumo vertinimą galima išskirti i 4 pagrindinius etapus (1 pav.): 


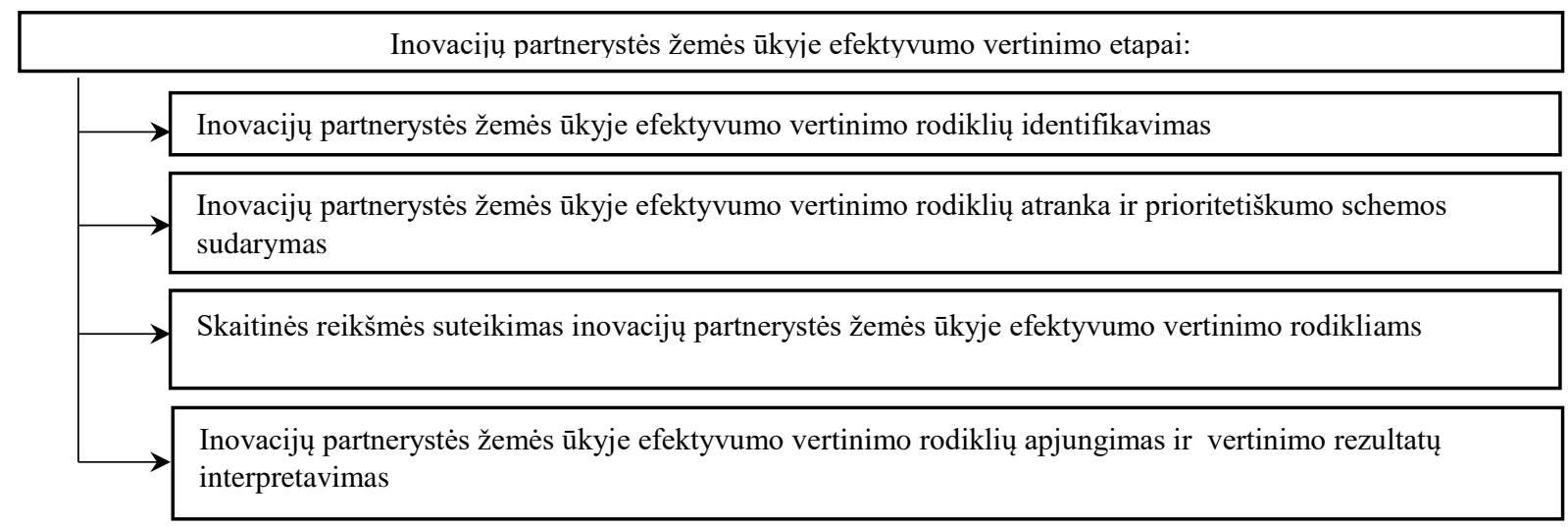

\section{1. pav. Inovacijų partnerystės žemės ūkyje efektyvumo vertinimo loginė schema}

Toliau detalizuojama kiekvienas inovacijų partnerystès žemès ūkyje efektyvumo vertinimo etapas.

\subsection{Inovacijų partnerystès žemė ūkyje efektyvumo vertinimo rodiklių identifikavimas ir atrinktų rodiklių prioritetiškumo schemos sudarymas}

Rodikliu atranka. Inovacijų partnerystės efektyvumo neịmanoma aprašyti vienu dydžiu, rodikliu, nes sunku rasti tokią jo savybę, kuri visapusiškai nusakytų EIP veiklos grupių efektyvumą. Siekiant išsamiau aprašyti ir teisingiau įvertinti inovacijų partnerystės žemės ūkyje efektyvumo vertinimą, svarbu vertinti įvairius rodiklius, geriausiai reprezentuojančius EIP veiklos grupès partnerių tarpusavio bendradarbiavimą, vykdomo EIP grupès projekto tikslus ir sprendžiamas problemas.

Inovacijų partnerystės žemės ūkyje efektyvumo vertinimui suformuotas išplèstinis rodiklių sąrašas (1. lentelè). Vadovaujantis inovacijų partnerystės žemès ūkyje koncepcija, visus EIP tikslus galima suskirstyti ị tris grupes: ekonominiai - socialiniai tikslai, technologinės inovacinès pažangos tikslai ir aplinkos apsaugos tikslai. Atsižvelgiant ị EIP tikslų grupavimą, EIP efektyvumo vertinimo rodikliai taip pat suskirstyti i 3 grupes: Socialiniai - ekonominiai (apimantys ir partneriu bendradarbiavimo efektyvumo rodiklius); Technologiniai; Aplinkos apsaugos.

1 lentelè. Inovacijų partnerystės žemès ūkyje efektyvumo vertinimo rodiklių sąrašas

\begin{tabular}{|c|}
\hline Rodikliai \\
\hline I. SOCIALINIŲ EKONOMINIŲ RODIKLIŲ GRUPE் \\
\hline 1.1. Finansinio plano vykdymo efektyvumas \\
\hline 1.2. Projekto valdymo, administravimo veiklos efektyvumas \\
\hline 1.3. EIP veiklos grupès narių įsitraukimas ị projekto veiklas \\
\hline $\begin{array}{l}\text { 1.4.Vertikalaus bendradarbiavimo tarp mokslininkų ir ūkininkų tarpininkaujant konsultantams efektyvumas užtikrinant abipusị ir } \\
\text { grižtamajjį ryši }\end{array}$ \\
\hline 1.5. Horizontalaus bendradarbiavimo projekte tarp ūkininkų efektyvumas \\
\hline 1.6. Efektyvus bendradarbiavimas ir patirties sklaida EIP-AGRI tinkle \\
\hline 1.7. Projekto rezultatų pritaikomumo pademonstravimas \\
\hline 1.8. Projekto rezultatų pasiekimo pažanga \\
\hline II. TECHNOLOGINIŲ RODIKLIŲ GRUPE் \\
\hline 2.1. Technologinio sprendimo pritaikomumas \\
\hline 2.2. Technologinis naujumas \\
\hline 2.3. Technologinis efektyvumas \\
\hline III. APLINKOS APSAUGOS RODIKLIŲ GRUPE் \\
\hline 3.1. Projektas skatina tvarų išteklių naudojimą \\
\hline 3.2. Projektas prisideda prie aplinkos išsaugojimo, prisitaikymo prie klimato kaitos pokyčių \\
\hline
\end{tabular}

Rodiklių reikšmingumui (svoriams) įvertinti naudotas ekspertinio vertinimo metodas. 
Šio metodo esminis principas yra tas, kad parenkama specialistu grupé, kurie analizuoja tyrimo problemą, kiekybiškai vertindami ir formaliai apdorodami duomenis, siekiant mokslinio objektyvumo.

Objektyvių tyrimo rezultatų galima tikètis tuomet, kai tyrime dalyvaujantys ekspertai yra kompetentingi nagrinètos problemos klausimu. Kadangi dažnai ekspertų žinios ir patirtis yra skirtinga, buvo nustatyti ekspertų atrankos kriterijai. Ekspertų atrankos kriterijai susiję su tyrime dalyvaujančių ekspertų profesine sritimi.

Ekspertinejje rodiklių atrankoje dalyvavo ilgametę mokslinę ir praktinę patirtị turintys ekspertai - iš viso 10 ekspertų. Ekspertai ịvertino kiekvieną, tyrëjų pateiktą rodiklị ir suteike jiems įvertinimus dešimties balų skalèje (10 balu-labai reikšmingas rodiklis, 1 balas - visai nereikšmingas rodiklis). Tyrëjai gautuosius ịvertinimus perskaičiavo nustatant rodiklio svorị grupèje bei apskaičiuojant standartinį nuokrypi (2. lentelè).

2 lentelè. Rodikliu prioritetiškumo schema

\begin{tabular}{|c|c|c|c|}
\hline Rodikliai & $\begin{array}{r}\text { Rodiklio } \\
\text { Svoris, \% }\end{array}$ & $\begin{array}{c}\text { Balų } \\
\text { vidurkis, } S\end{array}$ & $\begin{array}{l}\text { Standartinis } \\
\text { nuokrypis } \\
\text { balais, } \Delta S\end{array}$ \\
\hline \multicolumn{4}{|c|}{ I. SOCIALINIŲ EKONOMINIŲ RODIKLIŲ GRUPE் } \\
\hline 1.1. Finansinio plano vykdymo efektyvumas & 6,6 & 7,0 & 64,3 \\
\hline 1.2. Projekto valdymo, administravimo veiklos efektyvumas & 7,5 & 8,0 & 63,6 \\
\hline 1.3. EIP veiklos grupės nariu isitraukimas i projekto veiklas & 8,1 & 8,6 & 63,1 \\
\hline $\begin{array}{l}\text { 1.4. Vertikalaus bendradarbiavimo tarp mokslininkų ir ūkininkų } \\
\text { tarpininkaujant konsultantams efektyvumas užtikrinant abipusị ir } \\
\text { grįžtamajj ryši }\end{array}$ & 9,4 & 10,0 & 62,2 \\
\hline $\begin{array}{l}\text { 1.5. Horizontalaus bendradarbiavimo projekte tarp ūkininku } \\
\text { efektyvumas }\end{array}$ & 7,8 & 8,3 & 63,4 \\
\hline $\begin{array}{l}\text { 1.6. Efektyvus bendradarbiavimas ir patirties sklaida EIP-AGRI } \\
\text { tinkle }\end{array}$ & 7,5 & 8,0 & 63,6 \\
\hline 1.7. Projekto rezultatų pritaikomumo pademonstravimas & 8,1 & 8,6 & 63,1 \\
\hline 1.8. Projekto rezultatų pasiekimo pažanga & 8,1 & 8,6 & 63,1 \\
\hline \multicolumn{4}{|c|}{ II. TECHNOLOGINIU巳 RODIKLIŲ GRUPE் } \\
\hline 2.1. Technologinio sprendimo pritaikomumas & 7,8 & 8,3 & 63,4 \\
\hline 2.2. Technologinis naujumas & 7,5 & 8,0 & 63,6 \\
\hline 2.3. Technologinis efektyvumas & 7,6 & 8,1 & 63,8 \\
\hline \multicolumn{4}{|c|}{ III. APLINKOS APSAUGOS RODIKLIŲ GRUPE் } \\
\hline 3.1. Projektas skatina tvarų išteklių naudojimą & 6,8 & 7,2 & 64,1 \\
\hline $\begin{array}{l}\text { 3.2. Projektas prisideda prie aplinkos išsaugojimo, prisitaikymo } \\
\text { prie klimato kaitos pokyčiu }\end{array}$ & 6,9 & 7,3 & 64,1 \\
\hline
\end{tabular}

Kadangi tyrime dalyvaujančių ekspertų yra daugiau nei du, tai bendras ekspertų nuomonių suderinamumas nustatomas taikant Kendal konkordancijos koeficientą. Ekspertai vertino skirtingus veiksnius ir alternatyvas, todèl būtina suformuluoti hipotezes:

$H_{0}=$ ekspertu vertinimai prieštaringi (t. y. Kendal konkordancijos koeficientas lygus nuliui); $H_{A}=$ ekspertu vertinimai panašūs (t. y. Kendal konkordancijos koeficientas nelygus nuliui).

Ekspertų ịvertinti rodikliai buvo suranguoti pagal reikšmingumą.

Surangavus rodiklius konkordancijos koeficientas apskaičiuojamas pagal formulę:

$$
W=\frac{12 \mathrm{~S}}{\mathrm{r} 2 \mathrm{n}(\mathrm{n} 2-1)}
$$

čia $r$ - ekspertų skaičius, $n$ - vertinamų veiksnių skaičius, $S$ - veiksnių rangų sumų nuokrypių nuo bendro vidurkio kvadratų suma, skaičiuojama pagal formulę: 


$$
\mathrm{S}=\sum_{j=1}^{n}\left(r * j-\frac{1}{2} r(n+1)\right) 2
$$

Jeigu konkordancijos koeficiento reikšmė yra arti vieneto, tai rodo, kad ekspertų vertinimai neprieštaringi. $\mathrm{O}$ jeigu vertinimuose yra sutampančių rangų tai koeficientas skaičiuojamas pagal kitą formulę:

$$
\begin{aligned}
& W=\frac{12 \mathrm{~S}}{\mathrm{n} 2(\mathrm{~m} 3-\mathrm{m})-n \sum_{i-1}^{n} T i} \\
& \mathrm{Ti}=\sum_{k=1}^{H j}\left(h_{k}^{3}-h_{k}\right) \\
& \mathrm{Tj}=\sum_{k=1}^{H j}\left(h_{k}^{3}-h_{k}\right)
\end{aligned}
$$

čia $T_{j}$-j-ojo eksperto susietų rangų rodiklis; $H_{j}$ - lygių rangų j-ojo eksperto skaičius, $t_{i}$ - lygių rangų i-tasis grupès skaičius.

Konkordacijos koeficientas gali būti taikomas tuomet kai nustatyta jo ribinè reikšmè, rodanti kada ekspertų vertinimus dar galima laikyti suderintais. Kendal įrodė, jog jeigu objektų skaičius n>7, tai konkordancijos koeficiento reikšmingumas gali būti nustatytas naudojant $\mathrm{x}^{2}$ kriterijų (Čekanavičius, Murauskas, 2006; Podvezko, 2005; Kareivaitė, 2012; Gearhart et al, 2013):

$$
x^{2}=\operatorname{Wr}(\mathrm{n}-1)=\frac{12 S}{r n(n+1)} .
$$

Rudzkienė (2005) paaiškina sprendimo prièmimo taisyklę:

- Dydis $W^{*} m^{*}(k-1)$ turi $x^{2}$ skirsni su $f=k$ - 1 laisvès laipsniu ( $m$ - ekspertų skaičius; $k-$ ekspertizès objektų skaičius).

- Jeigu apskaičiuota statistikos $\mathrm{W}^{*} \mathrm{~m} *(\mathrm{k}-1)$ reikšmė prie pasirinkto reikšmingumo

\begin{tabular}{|c|c|}
\hline Rodikliai & $\begin{array}{c}\text { Kendal } \\
\text { konkordacijos } \\
\text { koeficientas }\end{array}$ \\
\hline \multicolumn{2}{|l|}{ I. SOCIALINIU EKONOMINIU RODIKLIU GRUPE் } \\
\hline 1.1. Finansinio plano vykdymo efektyvumas & 0,84 \\
\hline 1.2. Projekto valdymo, administravimo veiklos efektyvumas & 0,83 \\
\hline 1.3. EIP veiklos grupès narių isitraukimas i projekto veiklas & 0,80 \\
\hline $\begin{array}{l}\text { 1.4.Vertikalaus bendradarbiavimo tarp mokslininku ir ūkininkų tarpininkaujant konsultantams } \\
\text { efektyvumas užtikrinant abipusị ir grįžtamajị ryšị }\end{array}$ & 0,91 \\
\hline 1.5. Horizontalaus bendradarbiavimo projekte tarp ūkininku efektyvumas & 0,81 \\
\hline 1.6. Efektyvus bendradarbiavimas ir patirties sklaida EIP-AGRI tinkle & 0,84 \\
\hline 1.7. Projekto rezultatu pritaikomumo pademonstravimas & 0,82 \\
\hline 1.8. Projekto rezultatų pasiekimo pažanga & 0,81 \\
\hline \multicolumn{2}{|l|}{ II. TECHNOLOGINIŲ RODIKLIU巳 GRUPE் } \\
\hline 2.1. Technologinio sprendimo pritaikomumas & 0,79 \\
\hline 2.2. Technologinis naujumas & 0,81 \\
\hline 2.3. Technologinis efektyvumas & 0,83 \\
\hline \multicolumn{2}{|l|}{ III. APLINKOS APSAUGOS RODIKLIU GRUPE் } \\
\hline 3.1. Projektas skatina tvarų išteklių naudojimą & 0,83 \\
\hline 3.2. Projektas prisideda prie aplinkos išsaugojimo, prisitaikymo prie klimato kaitos $p$ & 0,82 \\
\hline
\end{tabular}
lygmens $\alpha$ ir laisvès laipsnių skaičius f viršija kritinę reikšmę, t. y. $=\mathrm{W}^{*} \mathrm{~m} *(\mathrm{k}-1)>0$, tai hipotezė H0, kad ekspertų vertinimai prieštaringi atmetama. Ekspertų nuomonių suderinamumas pateikiamas 3 lentelèje.

\section{3 lentelè. Ekspertų nuomonių suderinamumas pagal Kendal Konkordacijos koeficientą}


Ekspertinio vertinimo suderinamumas parodè, jog ekspertai vieningai reikšmingais laiko visus tyrimo vykdytojų numatytus rodiklius, todèl jie yra tinkami inovacijų partnerystės žemès ūkyje vertinimui atlikti.

\subsection{Skaitinės reikšmės suteikimas inovacijų partnerystės efektyvumo vertinimo rodikliams}

Siekiant objektyvių ir palyginamų inovacijų partnerystės žemės ūkyje efektyvumo vertinimo rezultatų, skaitine išraiška vertinimo rodikliams turi būti suteikta naudojant vieningus metodus. Dèl rodiklių îvairovès, dažnai sudètinga ar visai neįmanoma išreikšti rodiklių vieningais kiekybiniais rodikliais. Tuo atveju tikslinga naudoti skales, kurių pagalba rodikliui suteikiama skaitinè išraiška, t. y. rodikliai yra normalizuojami ị visiems rodikliams vienodą dydị. Kintamųjų analizei atlikti, gali būti naudojamos nominaliosios ar pavadinimų (angl. Nominal) ir rangų (angl. Ordinal) skalès (Williams, Monge, 2001; Pukènas, 2009). Nominalioji skalè skirsto objektus ị grupes, atsižvelgiant i tam tikrus požymius, tačiau grupėms nesuteikiama skaitinė reikšmė, o suteikiama vardinè prasmé (pvz.: profesija, šeiminė padėtis). Inovacijų partnerystès žemės ūkyje efektyvumo vertinimo rodiklių skaitinei reikšmei suteikti tikslinga naudoti tik rangų skales, t. y. atlikti rangavimą.

Rangų skalëje nustatoma objekto (reiškinio) vieta pagal pasirinktą požymị vienos rūšies objektų grupejje. Rangų skalè taikoma tada, kai objektus galima sutvarkyti (suranguoti) pagal matuojamojo požymio intensyvumą. Skirtingai nei nominaliosios matavimų skalès, rangų skalèse tiriamieji objektai gali būti sudèlioti matuojamo požymio didèjimo arba mažèjimo tvarka. Naudojant šią skalę galima teigti, kad vieno objekto požymio reikšmė didesnė, lygi ar mažesnè už kito objekto, nors neįmanoma nustatyti, kiek ji didesnė ar mažesnè (Baranauskiene, 2015). Podvezko (2008) nurodo, kad rangavimas yra procedūra, kai pačiam svarbiausiam objektui (rodikliui) suteikiamas rangas, lygus vienetui, antram pagal svarbumą - rangas 2 ir t. t., paskutiniam pagal svarbumą - rangas $m$; čia $m$ - lyginamųjų objektų (rodiklių) skaičius.

Idealioje rangų skalėje sutampančių verčių neturètų būti, tačiau praktikoje sutampančių rangu pasitaiko. Tokiais atvejais naudojama rangų skalès atmaina - balų matavimo skalé, kurioje objektas (rodiklis) pagal tam tikrą požymị ịvertinamas vienu iš skalès balų (Bilevičienė, Jonušauskas, 2013). rodikliai.

Vertinant EIP žemès ūkyje efektyvumą, išskiriami projektų rezultatų pasiekimo pažangos

Siekiant ịvertinti projektų rezultatų pasiekimo pažangos rodiklius, ekspertas pokalbio su EIP veiklos grupès nariais metu vertina:

a) projekto uždavinių ịgyvendinimą (projekto rezultatų rodiklių ịgyvendinimą);

b) projekto veiklų igyvendinimą (projekto pasiekimų rodiklių igyvendinimą).

Kiekvienas rezultato rodiklis įvertinamas 0-1-2 balų skalëje, kai:

2 balai - planuoti pasiekimai ir rezultatai pilnai pasiekti be jokių esminių trūkumų;

1 balas - planuoti pasiekimai ir rezultatai pasiekti su tam tikrais esminiais trūkumais;

0 balu - planuoti pasiekimai ir rezultatai nepasiekti.

Suteikiant skaitinę reikšmę kitiems inovacijų partnerystės efektyvumo vertinimo rodikliams (išskyrus projektų rezultatų pažangos) taip pat taikomos trijų balų skalès. Skalès rangas apibūdina tam tikru rodikliu išreikštą inovacijų partnerystès efektyvumo lygị. Inovacijų partnerystès veiklos efektyvumo vertinimo trijų rangų (balų) skalès skaitinių reikšmių apibūdinimas bendruoju atveju pateikiamas 4 lentelèje. 


\section{4 lentelè. Trijų rangų (balų) skalių skaitinių reikšmių apibūdinimas}

\begin{tabular}{|c|c|c|c|}
\hline Skaitinė reikšmė & 2 & $\mathbf{1}$ & $\mathbf{0}$ \\
\hline & Efektyvu & Vidutiniškai & Neefektyvu \\
\hline $\begin{array}{c}\text { Inovacijų } \\
\text { partnerystès } \\
\text { rodiklių } \\
\text { reikšmių } \\
\text { apibūdinimas }\end{array}$ & $\begin{array}{c}\text { Vertinamas rodiklis } \\
\text { igyvendinamas be esminių } \\
\text { trūkumų, kas leidžia daryti } \\
\text { prielaidą, jog projekto tikslai } \\
\text { yra maksimaliai pasiekti / bus } \\
\text { maksimaliai pasiekti (tarpinio } \\
\text { vertinimo atveju), gali būti } \\
\text { laikoma "gera praktika" }\end{array}$ & $\begin{array}{c}\text { Vertinamas rodiklis } \\
\text { igyvendintas / } \\
\text { igyvendinamas (tarpinio } \\
\text { vertinimo atveju) su } \\
\text { nežymiais trūkumais } \\
\text { projekto tikslu pasiekimo } \\
\text { atžvilgiu }\end{array}$ & $\begin{array}{c}\text { Vertinamas rodiklis } \\
\text { igyvendintas / igyvendinamas } \\
\text { (tarpinio vertinimo atveju) su } \\
\text { esminiais trūkumais ir yra } \\
\text { didele rizika, kad projekto } \\
\text { tikslai (ar dalis tikslų) nebus } \\
\text { pasiekti (tarpinio vertinimo } \\
\text { atveju) }\end{array}$ \\
\hline
\end{tabular}

Kaip atskaitos taškas, rangų (balų) skalèse imamas „, „ balų, jis atitinka apibūdinimą „neefektyvu“. 5 lentelëje aprašyti kiekvieno rodiklio įvertinimo kriterijai pagal skalę 0-1-2.

\section{5 lentelė. EIP žemės ūkyje efektyvumo rodiklių vertinimo kriterijai}

\begin{tabular}{|c|c|}
\hline Rodikliai & Ivertinimo kriterijai/klausimai ekspertiniam vertinimui \\
\hline \multicolumn{2}{|r|}{ I. SOCIALINIŲ EKONOMINIŲ RODIKLIŲ GRUPE் } \\
\hline $\begin{array}{l}\text { 1.1. Finansinio plano } \\
\text { vykdymo efektyvumas }\end{array}$ & $\begin{array}{l}\text { Ekspertas pokalbio su EIP veiklos grupés nariais metu vertina ar: } \\
\text { a) laiku pateikti mokèjimo prašymai; } \\
\text { b) kompensuotos visos paraiškoje numatytos išlaidos; } \\
\text { c) vykdoma finansinio plano ịgyvendinimo kontrolè; } \\
\text { d) finansinio plano pakeitimai (jei tokių buvo) būtini ir pagrịsti. }\end{array}$ \\
\hline $\begin{array}{l}\text { 1.2. Projekto valdymo, } \\
\text { administravimo veiklos } \\
\text { efektyvumas }\end{array}$ & $\begin{array}{l}\text { Ekspertas pokalbio su EIP veiklos grupės nariais metu vertina ar: } \\
\text { a) EIP grupès nariams pakanka informacijos apie priskirtas atsakomybes, projekto } \\
\text { igyvendinimo eigą, pasiekimus; } \\
\text { b) EIP grupés nariams pakanka techninės pagalbos tvarkant projekto dokumentaciją; } \\
\text { c) projekto administravimo grupè suteikia reikalingą informaciją, supažindina su projekto } \\
\text { tikslais, laukiamais rezultatais ir pan. projekto veiklų vykdytojus; } \\
\text { d) laiku derinami / pateikiami reikiami dokumentai, mokèjimo prašymai, ataskaitos } \\
\text { atsakingoms institucijoms; } \\
\text { e) projekto pakeitimai (jei tokių buvo) daromi laiku ir jie yra efektyvūs; } \\
\text { f) skaidrus ir savalaikis sprendimų prièmimas; } \\
\text { g) projekto administravimo grupè bendradarbiauja su Žemės ūkio ministerija, Nacionaline } \\
\text { mokejimo agentūra ir yra abipusis grįžtamasis ryšys. }\end{array}$ \\
\hline $\begin{array}{l}\text { 1.3. EIP veiklos grupès } \\
\text { nariu i isitraukimas i } \\
\text { projekto veiklas }\end{array}$ & $\begin{array}{l}\text { Ekspertas pokalbio su EIP veiklos grupès nariais metu vertina ar: } \\
\text { a) EIP veiklos grupės nariai vienodai ir tolygiai įsitraukè i projekto veiklas sprendžiant } \\
\text { ūkininkams aktualią konkrečią problemą; } \\
\text { b) EIP veiklos grupès nariai aktyviai dalyvavo projekto susitikimuose, seminaruose, } \\
\text { c) grupės nariai tolygiai prisidèjo prie projekto veiklų savo ištekliais ir žiniomis bei patirtimi. }\end{array}$ \\
\hline $\begin{array}{l}\text { 1.4.Vertikalaus } \\
\text { bendradarbiavimo tarp } \\
\text { mokslininkų ir } \\
\text { ūkininkų } \\
\text { tarpininkaujant } \\
\text { konsultantams } \\
\text { efektyvumas } \\
\text { užtikrinant abipusị ir } \\
\text { grįžtamajị ryši }\end{array}$ & $\begin{array}{l}\text { Ekspertas pokalbio su EIP veiklos grupès nariais metu vertina ar: } \\
\text { a) vyksta planuoti susitikimai; } \\
\text { b) aiškiai identifikuotos ūkininkavimo problemos kylančios iš ūkininkų poreikių; } \\
\text { c) konsultantai bendradarbiauja su ūkininkais ir mokslininkais; } \\
\text { d) mokslininkai diskutuoja su ūkininkais ir konsultantais pasirengdami ir išbandydami } \\
\text { inovacinị sprendimą; } \\
\text { e) vyksta informacijos apsikeitimas. }\end{array}$ \\
\hline $\begin{array}{l}\text { 1.5. Horizontalaus } \\
\text { bendradarbiavimo } \\
\text { projekte tarp ūkininkų } \\
\text { efektyvumas }\end{array}$ & $\begin{array}{l}\text { Ekspertas pokalbio su EIP veiklos grupės nariais metu vertina ar: } \\
\text { a) sprendžiamos problemos aktualios visiems ūkiams; } \\
\text { b) aptariamos rizikos; } \\
\text { c) dalijamasi geraja praktika ir demonstruojami pasiekimų rezultatai; } \\
\text { d) dalijamasi techniniais pajėgumais ir kitais ištekliais įgyvendinant projekto veiklas. }\end{array}$ \\
\hline $\begin{array}{l}\text { 1.6. Efektyvus } \\
\text { bendradarbiavimas ir } \\
\text { patirties sklaida EIP- } \\
\text { AGRI tinkle }\end{array}$ & $\begin{array}{l}\text { Ekspertas pokalbio su EIP veiklos grupès nariais metu vertina ar: } \\
\text { a) EIP veiklos grupés nariai prisiregistravę ir dalyvauja dalinantis patirtimi EIP-AGRI } \\
\text { tinkle; } \\
\text { b) EIP veiklos grupes nariai prisideda prie informacijos viešinimo EIP-AGRI tinkle. }\end{array}$ \\
\hline
\end{tabular}




\begin{tabular}{|c|c|}
\hline $\begin{array}{l}\text { 1.7. Projekto rezultatu } \\
\text { pritaikomumo } \\
\text { pademonstravimas }\end{array}$ & $\begin{array}{l}\text { Ekspertas pokalbio su EIP veiklos grupès nariais metu vertina ar: } \\
\text { a) projekto rezultatų pritaikomumas pristatomas viešuosiuose sklaidos renginiuose } \\
\text { (seminaruose, konferencijose, parodose, susitikimuose ir kt.), interneto tinklalapiuose; } \\
\text { b) projekto rezultatų pritaikomumas pademonstruotas numatytame ūkių skaičiuje; } \\
\text { c) projekto rezultatų demonstravimo priemonių vaizdingumas, vizualizacijos sprendimai. }\end{array}$ \\
\hline $\begin{array}{l}\text { 1.8. Projekto rezultatu } \\
\text { pasiekimo pažanga }\end{array}$ & $\begin{array}{l}\text { Ekspertas pokalbio su EIP veiklos grupés nariais metu vertina ar: } \\
\text { a) planuoti pasiekimai ir rezultatai pilnai pasiekti be jokių esminių trūkumų, su tam tikrais } \\
\text { trūkumais ar nepasiekti }\end{array}$ \\
\hline \multicolumn{2}{|r|}{ II. TECHNOLOGINIŲ RODIKLIŲ GRUPE் } \\
\hline $\begin{array}{l}\text { 2.1. Technologinio } \\
\text { sprendimo } \\
\text { pritaikomumas }\end{array}$ & $\begin{array}{l}\text { Ekspertas pokalbio su EIP veiklos grupès nariais metu vertina ar: } \\
\text { a) pakanka ūkyje esamos infrastruktūros techninio sprendimo pritaikymui; } \\
\text { b) pakanka materialinių išteklių techninio sprendimo pritaikymui. }\end{array}$ \\
\hline $\begin{array}{l}\text { 2.2. Technologinis } \\
\text { naujumas }\end{array}$ & $\begin{array}{l}\text { Ekspertas pokalbio su EIP veiklos grupès nariais metu vertina ar: } \\
\text { a) projekto metu pavyko sukurti, išplètoti, patobulinti produktus, procesus, technologijas. }\end{array}$ \\
\hline $\begin{array}{l}\text { 2.3.Techologinis } \\
\text { efektyvumas }\end{array}$ & $\begin{array}{l}\text { Ekspertas pokalbio su EIP veiklos grupès nariais metu vertina ar: } \\
\text { a) pritaikytas technologinis sprendimas atitiko lūkesčius; } \\
\text { b) įdiegta, patobulinta technologija išsprendè problemą; } \\
\text { c) technologinis sprendimas pasiteisino kaštų - naudos atžvilgiu }\end{array}$ \\
\hline \multicolumn{2}{|r|}{ III. APLINKOS APSAUGOS RODIKLIŲ GRUPE் } \\
\hline $\begin{array}{l}\text { 3.1. Projektas skatina } \\
\text { tvarų išteklių } \\
\text { naudojimą }\end{array}$ & $\begin{array}{l}\text { Ekspertas pokalbio su EIP veiklos grupès nariais metu vertina ar: } \\
\text { a) projektas skatina efektyviai naudoti išteklius (vandens, dirvožemio, elektros, kuro ir pan.); } \\
\text { b) projektas susijęs su ekologine gamyba; } \\
\text { c) projektas turès įtakos aplinkos taršos sumažinimui. }\end{array}$ \\
\hline $\begin{array}{l}\text { 3.2. Projektas } \\
\text { prisideda prie aplinkos } \\
\text { išsaugojimo, } \\
\text { prisitaikymo prie } \\
\text { klimato kaitos pokyčių }\end{array}$ & $\begin{array}{l}\text { Ekspertas pokalbio su EIP veiklos grupės nariais metu vertina ar: } \\
\text { a) projekto metu tobulinami procesai, technologijos, kuriais siekiama išsaugoti aplinką } \\
\text { b) projektas skatina prisitaikyti prie klimato kaitos ir ją sušvelninti }\end{array}$ \\
\hline
\end{tabular}

Siekiant suformuluoti išvadas apie vertinamo EIP projekto efektyvumą, vertinamus rodiklius tikslinga apjungti.

\section{interpretavimas \\ 2.4. Vertinamų rodiklių reikšmių apjungimas ir gautų vertinimo rezultatų}

Vertinamų rodiklių reikšmių apjungimas atliekamas trimis etapais:

1. Vertinamu rodikliu reikšmiu apjungimas. Atskirų vertinamų rodiklių skaitines reikšmes galima apjungti sumuojant atskirų rodiklių skaitinių reikšmių ir svorių sandaugas:

$$
S=\sum_{i=1}^{m} m_{i} r_{i}
$$

čia: $\mathrm{S}$ - vertinamų rodiklių skaitinių reikšmių suma; $\mathrm{m}_{\mathrm{i}}$ - $\mathrm{i}$-ojo rodiklio skaitinè reikšmė; $\mathrm{r}_{\mathrm{i}}$ - i-ojo rodiklio reikšmingumas (svoris).

2. Nustatomas maksimalus rodikliu reikšmiu balas konkretaus vertinimo atveju. Konkretaus EIP veiklos grupès efektyvumo vertinimo metu gali būti naudojami ne visi vertinimo rodikliai, todèl konkrečiam atvejui nustatomas maksimalus galimas rodiklių reikšmių balas, t. $\mathrm{y}$. apskaičiuojama balų suma, kai kiekvienam vertinama rodikliui skiriamas maksimalus balas:

$$
S_{\max }=\sum_{i=1}^{m} m_{i \max } r_{i}
$$

čia: $\mathrm{S}_{\max }$ - vertinamų rodiklių skaitinių reikšmių maksimali suma; $\mathrm{m}_{\mathrm{i} \text { max }}$ - i-ojo rodiklio maksimali skaitinè reikšmé; $r_{i}$ - i-ojo rodiklio reikšmingumas (svoris).

3. EIP veiklos grupès efektyvumo vertinimo rezultatų interpretavimas. Gautų EIP žemès ūkyje efektyvumo vertinimo rezultatų interpretavimui tikslinga sudaryti matricą, pagal kurią galima nustatyti bendrą inovacijų partnerystės efektyvumo lygị.

Apibendrinus ekspertų nuomonę buvo nustatyta, jog: 
- EIP veiklą galima laikyti efektyvia, kai vertinimo metu surenkama daugiau nei 85 proc. maksimaliai galimų surinkti balų sumos;

- EIP veiklą galima laikyti patenkinamai efektyvia, kai vertinimo metu surenkama 50-85 proc. maksimaliai galimų surinkti balų sumos;

- EIP veiklą galima laikyti neefektyvia, kai vertinimo metu surenkama mažiau nei 50 proc. maksimaliai galimų surinkti balų sumos.

6 lentelëje sudaryta EIP žemès ūkyje efektyvumo vertinimo matrica.

6 lentelè. EIP žemès ūkyje efektyvumo vertinimo matrica

\begin{tabular}{|l|c|}
\hline \multicolumn{1}{|c|}{ EIP veiklos efektyvumo lygis } & Ivertinimo intervalas \\
\hline EIP veikla efektyvi & Daugiau nei 85 proc $S_{\max }$ \\
\hline EIP veikla patenkinamai efektyvi & $50-85$ proc. $S_{\max }$ \\
\hline EIP veikla neefektyvi & Mažiau nei 50 proc. $S_{\max }$. \\
\hline
\end{tabular}

Atsižvelgiant ị vertinamų rodiklių skaitinių reikšmių sumą ir vertinamų rodiklių skaitinių reikšmių maksimalią sumą bei detalizuotais EIP veiklos grupių efektyvumo ivvertinimo interpretavimo intervalais, nustatomas kiekvienos EIP veiklos grupès projekto efektyvumo lygis, įvertinant kiek procentų nuo maksimalios rodiklių reikšmių sumos sudaro EIP veiklos grupės projekto efektyvumo vertinimo balas.

Apibendrinant galima teigti, kad inovacijų partnerystės žemès ūkyje efektyvumo vertinimui gali būti pasirenkami ịvairūs efektyvumo vertinimo rodikliai, kurie suranguojami pagal trijų rangu skalę, o gauti rezultatai interpretuojami vadovaujantis sudarytomis EIP efektyvumo vertinimo matricomis, kurios nusako EIP veiklos efektyvumo lygi.

Sudaryta inovacijų partnerystès žemès ūkyje efektyvumo vertinimo metodika buvo testuota naudojant Lietuvos EIP projektų duomenis. EIP veiklos grupių projektų atrankai panaudoti atvejo analizès (angl. Case Study) metodui būdingi atvejo parinkimo principai, juos apibūdina Gerring (2001, 2004, 2007), Seawright, Gerring, (2008), Creswell (2014) ir kiti mokslininkai. Minèti autoriai pažymi, kad atvejų parinkimas analizei priklauso nuo kiekvieno konkretaus mokslinio tyrimo ir vieno visose situacijose tinkamo atvejų parinkimo metodo nèra. Pirmiausia, parinktas atvejis turi kuo geriau atskleisti, padèti igyvendinti mokslinio tyrimo tikslus, tačiau neturi kryptingai formuoti vienokio ar kitokio laukiamo tyrimo rezultato.

Apibendrinant galima teigti, kad sudaryta EIP žemės ūkyje efektyvumo vertinimo metodika yra empiriškai patikima ir leidžia įvertinti EIP veiklos grupių veiklos efektyvumą.

\section{Išvados}

Sudaryta inovacijų efektyvumo žemès ūkyje vertinimo metodika pagrista vertinimo principais: nuoseklumo, paprastumo, pagrịstumo, palyginamumo, plataus pritaikomumo. Inovacijų partnerystès žemès ūkyje efektyvumo vertinimo prielaidos: inovacijų partnerystės žemès ūkyje efektyvumo vertinimo metodika skirta EIP veiklos gupių veiklos ar jų vykdomų projektų vertinimui, kai veiklos poveikis tiesiogiai nukreiptas ị konkrečių žemès ūkio problemų sprendimą, atsiribojant nuo išskirtinių atvejų, eksperimentų, kuriems esant laukiamas ir modeliuojamas neịprastas bendradarbiavimas ir dẻl to atsirandantis neịprastas veiklų poveikis. Inovacijų efektyvumo žemės ūkyje vertinimo metodika sudaro 4 etapai: 1) efektyvumo vertinimo rodiklių identifikavimas, 2) rodiklių atranka ir prioritetiškumo schemos sudarymas; 3) skaitinès reikšmès suteikimas vertinamiems rodikliams; 4) rodiklių apjungimas ir vertinimo rezultatų interpretavimas.

Inovacijų partnerystės žemès ūkyje efektyvumo vertinimui sudarytas išplèstinis rodiklių sąrašas. Vadovaujantis inovacijų partnerystės žemės ūkyje koncepcija, visus EIP tikslus galima suskirstyti ị tris grupes: ekonominiai - socialiniai tikslai, technologinès inovacinės pažangos tikslai ir aplinkosauginiai tikslai. Atsižvelgiant į EIP tikslų grupavimą, EIP efektyvumo vertinimo rodikliai taip pat suskirstyti i 3 grupes. Rodiklių reikšmingumui (svoriams) įvertinti naudotas ekspertinio 
vertinimo metodas. Ekspertinèje rodiklių atrankoje dalyvavo ilgametę mokslinę ir praktinę patirti turintys ekspertai. Ekspertai įvertino kiekvieną rodiklị ir suteikè jiems balus, kuriems buvo suteikti svoriai rodiklio grupeje.

Suteikiant skaitinę reikšmę inovacijų partnerystės efektyvumo vertinimo rodikliams taikomos trijų rangų (balų) skalès. Skalès rangas apibūdina tam tikru rodikliu išreikštą inovacijų partnerystès efektyvumo lygị. Sudarytoje metodikoje detalizuota kiekvieno rodiklio įvertinimo (balo priskyrimo) kriterijai.

Inovacijų partnerystės žemès ūkyje efektyvumo vertinimo rezultatų interpretavimui sudaryta matrica, pagal kurią nesudètinga nustatyti bendrą inovacijų partnerystès efektyvumo lygị. Apskaičiavus bendrą inovacijų partnerystès efektyvumo vertinimo balų skaičių, pagal ekspertų sudarytus intervalus, nustatomas bendras inovacijų partnerystės efektyvumas: 1) veikla efektyvi; 2) veikla patenkinamai efektyvi; 3) veikla neefektyvi.

Inovacijų partnerystės žemės ūkyje efektyvumo vertinimo metodika empiriškai patikrinta. Pasirinktų EIP veiklos grupių projektai buvo vertinami ekspertų pagal sudarytą efektyvumo vertinimo rodiklių sąrašą, kiekvieną rodiklị įvertinant trijų balų skalèje, atsižvelgiant ị metodikoje išdèstytus vertinimo kriterijus. Vadovaujantis vertinamų efektyvumo rodiklių reikšmingumo svoriais buvo apskaičiuotas bendras EIP veiklos grupès efektyvumas ir nustatyta, ar EIP veiklos grupès veikla yra efektyvi.

Tolimesni moksliniai tyrimai gali būti siejami su Inovacijų partnerystės žemès ūkyje efektyvumo vertinimo metodikos empiriniu patikrinimu ir pritaikymu, kai pasirenkami skirtingų ūkio šakų projektai, skirtingose šalyse.

\section{Literatūra}

Aparicio, J., Lovell, C. A. K., Pastor, J. T. (2016). Advances in Efficiency and Productivity. Springer International Publishing.

Baranauskienè, J. (2015). Viešujų investicijų projektų kuriamos socialinès naudos kompleksinis vertinimas. Daktaro disertacija: socialinių mokslų sritis, ekonomikos kryptis (04S). Kaunas, Aleksandro Stulginskio universitetas, p. 204.

Bilevičienė, T., Jonušauskas, S. (2013). Atvirojo kodo programų taikymas rinkos tyrimuose. Vilnius: Mykolo Romerio universitetas.

Common evaluation questions for RDP programmes 2014-2020 (2015), Prieiga internetu: https://enrd.ec.europa.eu/sites/enrd/files/uploaded-files/wp_evaluation_questions 2015.pdf (2020 10 25)

Creswell J. W. (2014). Qualitative, Quantitative, and Mixed Methods Approaches (4th edition). University of Nebraska-Lincoln, p. 256.

Čekanavičius, V., Murauskas, G. (2006). Statistika ir jos taikymas. Vilnius: leidykla TEV. T.1.; p. 238.

Dudycz, T., Osbert-Pociecha, G., \& Brycz, B. (Eds.). (2017). Efficiency in Business and Economics: Proceedings from the 7th International Conference on Efficiency as a Source of the Wealth of Nations (ESWN), Wrocław 2017. Springer.

Edlin, R., McCabe, C., Hulme, C., Hall, P., \& Wright, J. (2015). Cost effectiveness modelling for health technology assessment. Heidelberg: Springer.

Ernst, R. 2006. Indirect Costs and Cost-Effectiveness Analysis //Value in Health, Nr. 9(4), p. 253-261.

EUROPEAN COMMISSION - Directorate-General for Agriculture and Rural Development - Unit C.4 (2017): Guidelines. Evaluation of innovation in rural development programmes 2014-2020.

Europos Komisijos strateginis planas žemès ūkiui 2016-2020. Prieiga per internetą: http://ec.europa.eu/info/publications/strategic-plan-2016-2020-agriculture_en (2020 10 25).

Gearhart, A. D., Sedivec T. B. K \& Schauer Ch. (2013) Use of Kendall's coefficient of concordance to assess agreement among observers of very high resolution imagery // Geocarto International, 28:6, p. 517-526.

Gerring, J. (2001). Social science methodology: A criterial framework. Cambridge, UK: Cambridge University

Press.

Gerring, J. (2004). What is a Case Study and what is it good for? American Political Science Review 98, p. 341354.

Gerring, J. (2007) Case Study Research. Principles and Practices, Cambridge University Press, Cambridge.

Kareivaite, R. (2012). Kompleksinis darnaus vystymosi vertinimas taikant daugiakriterinius metodus. Daktaro disertacija: socialinių mokslų sritis, ekonomikos kryptis (04S). Kaunas, Vytauto Didžiojo universitetas, p. 204.

Kohno, H. (2016). Economic Effects of Public Investment: An Emphasis on Marshallian and Monetary External Economies (Vol. 1). Springer. 
Linzalone, R. Schiuma, G. 2015. A review of program and project evaluation models. // Measuring Business Excellence, Nr. 19(3), p. 90-99

Maziliauskas, A., Baranauskienè, J., Pakeltienè, R. (2018). Factors of effectiveness of European Innovation Partnership in agriculture // Management theory and studies for rural business and infrastructure development. 40 (2), $\mathrm{p}$. 216-231 $101-107$

Podvezko, V. (2005). Ekspertų įverčių suderinamumas. Ūkio technologinis ir ekonominis vystymasis. 9(2), p.

Podvezko, V. (2008). Sudètingų dydžių kompleksinis vertinimas // Verslas: teorija ir praktika, 9(3), p. 160-168.

Pukènas, K. (2009). Kokybinių duomenų analizė SPSS programa. Kaunas: Lietuvos kūno kultūros akademija, p. 94.

Rudzkienė, V., (2005) Socialinè statistika: vadovèlis. - Vilnius: Mykolo Romerio. universiteto Leidybos centras, 2005. $-260 \mathrm{p}$.

Seawright, J., Gerring, J. (2008) Case Selection Techniques in Case Study Research: A Menu of Qualitative and Quantitative Options. Political Research Quarterly 61; p. 294

Silvia Nanni, Catherine Bowyer, Marianne Kettunen \& Anastasia Giadrossi Assessing contribution towards the SDG's? Guidance for evaluating bio-based projects. IEEP guidance paper July 2020. Prieiga internetu: https://biconsortium.eu/sites/biconsortium.eu/files/downloads/Guidance\%20for\%20assessing\%20bio-

based\%20projects\%27\%20contribution\%20towards\%20the\%20SDGs.pdf (2020 1025 ).

The European Green Deal. European Commission 2019. Prieiga internetu: https://eur-lex.europa.eu/legalcontent/EN/TXT/?qid=1588580774040\&uri=CELEX:52019DC0640 (2020 10 25).

Transforming our world: the 2030 Agenda for Sustainable Development Resolution adopted by the General Assembly on 25 September 2015 Prieiga internetu: https://upload.wikimedia.org/wikipedia/commons/d/d5/N1529189.pdf (2020 10 25).

Vaitkevičiūtè, V. (2001). Tarptautinių žodžių žodynas- Vilnius

Williams, F., Monge, P.R. (2001). Reasoning with statistics: How to read quantitative research. (5th ed.). New York: Harcourt.

\title{
EVALUATION OF INNOVATION PARTNERSHIP EFFECTIVENESS IN AGRICULTURE
}

\author{
Jurgita Baranauskienė, Rasa Pakeltienė, Antanas Maziliauskas \\ Vytautas Magnus University \\ Address: Universiteto 10, 53361 Akademija, Kaunas disctrict, Lithuania
}

\section{Summary}

The European Innovation Partnership in Agriculture (EIP-AGRI) was initiated by the European Commission for social benefits and the modernization of the overall economy through innovation. Better and faster results are expecting by fostering collaboration between scientists, agricultural advisors and farmers. The main problem is how to evaluate the effectiveness of innovation partnership projects in agriculture, with what indicators to define and measure it? To address this problem, a methodology for evaluating the effectiveness of innovation partnerships in agriculture has needed. This article presents the methodology of evaluation of the effectiveness of innovation partnership in agriculture, which details the selected evaluation indicators, determines their significance, and provides guidelines for the interpretation of the results of efficiency evaluation. The developed evaluation methodology has tested using the project data of EIP groups operating in Lithuania. The methodology for evaluating the effectiveness of innovation partnerships in agriculture is relevant from both a scientific and practical point of view.

Keywords: innovation partnership, effectiveness, agriculture.

JEL Codes R10, R11, R58. 